\title{
ANALISIS PENGARUH MOTIVASI DAN GAYA KEPEMIMPINAN TERHADAP KINERJA KARYAWAN BANK BTPN PURNA BAKTI CABANG KUTACANE ACEH TENGGARA
}

\author{
Ardi Hirmansah \\ Fakultas Ekonomi, Program Studi Manajemen, Universitas Gunung Leuser Aceh \\ Jalan Iskandar Muda No. 1 Babussalam Kutacane 24651 Telp. (0629) 523281. Fax (0629) 523281 \\ e-mail: ardihirmansah36@gmail.com
}

\begin{abstract}
ABSTRAK
Perusahaan sangat bergantung pada penggunaan seluruh sumber daya yang ada, hal ini berguna untuk menghasilkan barang atau jasa yang dapat dipasarkan guna mencapai tujuan sebagaimana yang diharapkan perusahaan.Sumber daya tersebut dapat berupa modal, mesin dan manusia. Apabila keseluruhan modal ini dapat dikelola dengan baik maka perusahaan dapat dengan mudah mencapai tujuannya. Sikap menghargai sumber daya yang ada dalam perusahaan akan meningkatkan banyak aspek dalam manusia yang ada dalam perusahaan diantaranya kinerja dan kepuasan terhadap kerjanya. Kepuasan kerja sangat dipengaruhi oleh komitmen perusahaan dalam menjaga atau mensejahterakan pekerjanya seperti yang pernah diutarakan oleh Koh dan Boo pada tahun 2004 menyatakan hubungan yang positif dan signifikan antara kepuasaan kerja dengan komitmen perusahaan, hal ini dapat dinyatakan bahawa semakin tinggi kepuasan kerja semakin tinggi juga komitmen peruhaan yang ditujukan. Dapat dikatakan bahwa kepuasan kerja menyebabkan peningkatan kinerja sehingga pekerja yang merasa puas dalam bekerja akan mengalami peningkatan produktifitas diri, di sisi lain dapat pula terjadi kepuasan kerja yang disebabkan oleh adanya kinerja sehingga pekerja yang lebih produktif akan mendapatkan kepuasan kerja dan kinerja pekerja. Beberapa faktor dapat mempengaruhi kinerja karyawan. Faktor-faktor yang dapat mempengaruhi kinerja pegawai antara lain sikap (motivasi kerja, disiplin kerja, etos kerja), pendidikan, keterampilan, kepemimpinan, pendapatan, disiplin, komunikasi, sarana prasarana, dan kesempatan berprestasi. Gaya kepemimpinan adalah pola perilaku yang dirancang untuk mengintegrasikan tujuan organisasi untuk mencapai tujuan tertentu yang harus diupayakan oleh para pemimpin untuk meningkatkan kemampuannya dalam memberikan kepemimpinan. Kepemimpinan yang baik dapat memotivasi karyawan untuk bekerja sama mencapai tujuan yang diinginkan untuk kinerja yang tinggi.
\end{abstract}

Kata kunci: Motivasi, Gaya Kepemimpinan, Kinerja Pekerja

\begin{abstract}
Companies are very dependent on the use of all existing resources, this is useful for producing goods or services that can be marketed in order to achieve the goals as expected by the company. These resources can be in the form of capital, machines and humans. If all this capital can be managed properly then the company can easily achieve its goals. The attitude of appreciating the existing resources in the company will improve many aspects of the people in the company including performance and satisfaction with their work. Job satisfaction is strongly influenced by the company's
\end{abstract}


commitment to maintaining or prospering its workers as stated by Koh and Boo in 2004 stating a positive and significant relationship between job satisfaction and company commitment, it can be stated that the higher the job satisfaction, the higher the company commitment. aimed. It can be said that job satisfaction causes an increase in performance so that workers who are satisfied at work will experience an increase in self-productivity, on the other hand there can also be job satisfaction caused by performance so that more productive workers will get job satisfaction and worker performance. Employee performance can be influenced by several factors. Factors that can affect employee performance include mental attitude (work motivation, work discipline, work ethic), education, skills, leadership, income level, discipline, communication, infrastructure, achievement opportunities. Leadership style is a pattern of behavior designed to integrate organizational goals with the aim of achieving a certain goal, the leader must strive to improve his ability to provide leadership. A good leadership style will be able to influence employees to work together in achieving the desired goals to achieve high performance figures.

Keywords: Motivation, Leadership Style, Worker Performance

\section{PENDAHULUAN}

\section{Latar Belakang}

Karyawan adalah faktor yang penting dari sebuah perusahaan dan dari karyawanlah perusahaan tersebut bisa mencapai tujuan perusahaan yang telah ditetapkan. Karyawan yang menghasilkan pelayanan berkualitas akan memberikan dampak yang baik pula bagi perusahaan. Kualitas akan terjaga dengan baik apabila perusahaan tersebut akan terus bergerak dan maju. Kinerja para karyawan perusahaan merupakan fondasi dasar yang harus dibangun, dijaga dan di kembangkan dalam perusahaan agar memberikan dampak yang positif bagi perusahaan baik dalam kualitas maupun kuantitasnya. Berbagai macam faktor permasalahan yang ada akan memberikan dampak bagi pencipta tenaga kerja yang ada.Kinerja karyawan dapat dipengaruhi oleh beberapa faktor. Faktor-faktor yang dapat mempengaruhi kinerja karyawan antara lain adalah sikap mental (motivasi kerja, disiplin kerja, etika kerja), pendidikan, ketrampilan, kepemimpinan, tingkat penghasilan, kedisiplinan, komunikasi, sarana pra sarana, kesempatan berprestasi. Asset pada sebuah perusahaan merupakan penentu bergeraknya sebuah perusahaan, keseluruhan asset adalah sangat penting, terutama asset sumber daya manusia, orang ataupun manusia merupakan sumber daya yang selalu ada dalam sebuah perusahaan dan asset ini masuk dalam struktur organisasi sehingga menjadi penentu tercapainya tujuan perusahaan.Sumber daya manusia mempengaruhi efisiensi dan effektifnya perusahaan dalam merancang dan memproduksi barang dan jasa, mengawasi kualitasnya, memasarkan produk, mengalokasikan sumberdaya yang ada dalam menentukan tujuan perusahaan.

Kinerja organisasi berkaitan erat dengan kinerja sumber daya manusia yang ada didalamnya.Sehingga dapat diartikan kualitas manusia yang ada dalam sebuah organisasi menjadi tolak ukur keberhasilan dalam mencapai tujuan sebuah organisasi.Kinerja dapat dikatakan meningkat dan semakin berkualitas apabila individu dalam sebuah organisasi berhasil dalam mencapai standard kerja yang telah ditetapkan (As'ad, 2005) dan dijadikan sebagai acuan dalam penentu keberhasilan seorang individu dalam bekerja. Hal lain yang mempengaruhi kinerja pegawai adalah motivasi. Motivasi merupakan kekuatan pendorong yang ada dalam diri seseorang dalam melaksanakan suatu kegiatan.Motivasi berpotensi sebagai salah satu sarana terpenting dalam membentuk kepuasan kerja serta mempengaruhi kinerja pegawai.Pegawai dengan motivasi yang tinggi akan memiliki semangat kerja tinggi dan hal tersebut akan meningkatkan kinerjanya (Beal dan Steven, 2007). Hal senada jugadiungkapkan oleh EK dan Mukuru (2013), terdapat hubungan yang kuat diantara 
motivasi dengan kinerja pegawai.Sehingga permasalahan mengenai bagaimana peningkatan motivasi pegawai harus mendapat perhatian yang lebih dari sebuah organisasi.

\section{Tujuan Penelitian}

Adapun tujuan penelitian yang ingin dicapai penulis adalah Untuk mengetahui pengaruh terkait motivasi, gaya kepemimpinan serta kinerja dalam lingkup yang lebih kompleks serta pembagian kerja karyawan yang lebih terprosedur.

Motivasi

\section{LANDASAN TEORI}

Menurut Robbins (2010) motivasi merupakan salah satu cara seorang pekerja memuaskan keinginannya, hal ini dapat diartikan bahwa pekerja telah dipenuhi kebutuhannya oleh faktor tertentu maka perkerja akan mengerahkan segala upaya untuk menghasilkan pekerjaan yang terbaik guna mencapai tujuan organisasi. Cong dan Van (2013) menjelaskan motivasi sebagai seperangkat faktor yang membuat seorang pegawai melaksanakan tugasnya dengan cara yang khusus. Menurut Siagian (2003) motivasi adalah semangat bagi pekerja dalam memberikan kontribusi dalam mencapai tujuan organisasinya. Sutrisno (2009) menyatakan bahwa motivasi merupakan sebuah faktor yang mendorong atau menyemangati seseorang untuk melaksanakan sebuah aktivitas tertentu.

Kesediaan seseorang mengeluarkan kemampuannya juga dapat menunjukkan seseorang yang memiliki motivasi yang tinggi, hal ini seperti yang diterangkan oleh sedarmayanti (2007) yang mengungkapkan bahwa motivasi membuat pekerja mengeluarkan kemampuan yang maksimal kearah tujuan organisasi yang dikondisikan oleh kemampuan untuk memenuhi kebutuhan individual. Motivasi juga berkaitan dengan antusiasisme intrinsic (Chaidhary, 2012) tenaga pendorong seseorang untuk berbuat sesuatu (Buchori, 2004). Berdasarkan pendapat beberapa ahli berkaitan dengan motivasi diatas maka dapat dinyatakan bahwa motivasi merupakan tenaga pekerja dalam menggerakkan diri serta mendorong dalam bekerja bagi mencapai tujuan organisasi namun tidak meninggalkan tujuan pribadi.

Indikator motivasi

Teori Hierarki kebutuhan Abraham Maslow yang dikutip Robbins (2015), mengemukakan lima kesimpulan yang ada dalam setiap kebutuhan manusia yaitu:

a) Fisiologis, meliputi sandang, pangan dan papan

b) Rasa aman, meliputi perlindungan fisik dan emosional dan keamanan.

c) Social, meliputi persahabat, penerimaan dari lingkungan, kasih sayang

d) Penghargaan, meliputi harga diri, pencapaian, perhatian dan pengakuan

e) Aktualisasi meliputi pertumbuhan, mencapai potensi diri dan pemenuhan diri.

Maslow berpendapat bahwa kebutuhan yang diinginkan manusia itu bertahap, apabila kebutuhan pada level pertama yaitu fisiologi telah didapatkan maka kebutuhan kedua yaitu kebutuhan keamanan dan keselamat akan muncul menjadi kebutuhan yang utama. Selanjutnya apabila level kedua telah terpenuhi maka kebutuhan ketiga yaitu kebutuhan social akan muncul menjadi kebutuhan utama dan begitu juga untuk kebutuhan keempat dan kelima. Kebutuhan yang telah terpenuhi dan tercapai tidak akan menjadi dominasi atau motivasi lagi sehingga seseorang akan menjadikan level selanjutnya menjadi motivasi yang utama, walau bagaimanapun tidak ada kebutuhan yang terpuaskan sepenuhnya (robbins 2015). Menurut Maslow apabila kita ingin memotivasi seseorang maka kita perlu memahami keberadaan level kebutuhan seseorang serta pusatkan perhatian pada kebutuhan level tersebut maupun level diatasnya.

\section{Gaya Kepemimpinan}

Pelaksanaan kepemimpinan cenderung menumbuhkan kepercayaan, partisipasi, loyalitas, dan internal motivasi para bawahan dengan cara persuasif, hal ini semua akan 
diperoleh karena kecakapan, kemampuan, dan perilaku pimpinan tersebut. Menurut Malayu Hasibuan, (2006:169) ada beberapa tipe, di antaranya:

a. Tipe karismatis

Tipe pemimpin ini memiliki kekuatan energi, daya tarik dan pembawaan yang luar biasa untuk mempengaruhi orang lain, sehingga ia mempunyai pengikut yang sangat besar jumlahnya dan dapat dipercaya. Memiliki inspirasi, keberanian dan berkeyakinan teguh pada pendirian sendiri.

b. Tipe paternalistis dan maternalistis

Tipe paternalitis selalu menganggap bawahannya sebagai manusia yang tidak atau belum dewasa. Terlalu bersikap melindungi dan jarang memberikan kesempatan kepada karyawan untuk mengambil keputusan sendiri. Sedangkan untuk kepemimpinan tipe maternalitis memiliki ciri yang hampir mirip dengan paternalistis. Namun yang membedakan adalah sikap terlalu melindungi yang lebih menonjol, disertai dengan kasih sayang yang berlebihan.

c. Tipe militeristis

Perlu dipahami bahwa tipe kepemimpinan militeristis itu berbeda dengan kepemimpinan organisasi militer. Sifat dari pemimpin yang militeristis antara lain lebih banyak menggunakan sistem perintah terhadap bawahannya dan seringkali kurang bijaksana. Menghendaki kepatuhan mutlak dari bawahan. Menyenangi formalitas, menuntut adanya disiplin keras dan komunikasi yang berlangsung searah juga merupakan sifat dari pemimpin militeristis.

d. Tipe otokratis

Sifat dari pemimpin yang otokratis adalah memberikan perintah-perintah yang dipaksakan dan harus dipatuhi. Tidak pernah memberikan informasi secara detail tentang rencanarencana yang akan datang. Setiap perintah dan kebijakan ditetapkan tanpa berkonsultasi dengan bawahannya. Semua pujian dan kritik terhadap segenap anak buah diberikan atas pertimbangan pribadi pemimpin sendiri.

e. Tipe laisser faire

Tipe kepemimpinan laisser faire praktis tidak memimpin. Dia membiarkan kelompoknya dan setiap orang berbuat semau sendiri. Pemimpin tidak berpartisipasi sedikit pun dalam kegiatan kelompoknya. Semua pekerjaan dan tanggung jawab harus dilakukan oleh bawahan sendiri. Pemimpin laisser faire biasanya tidak memiliki keterampilan teknis.

f. Tipe populistis

Kepemimpinan populistis berpegang teguh pada nilai-nilai masyarakat yang tradisional. Juga kurang mempercayai dukungan kekuatan serta bantuan luar negeri.

g. Tipe administratif

Tipe ini mampu menyelenggarakan tugas-tugas administratif secara efektif. Sedangkan para pemimpinnya terdiri dari para teknorat dan para administrator yang mampu menggerakkan dinamika modernisasi dan pembangunan.

h. Tipe demokratis

Kepemimpinan demokratis berorientasi pada manusia, dan memberikan bimbingan yang efesien kepada para pengikutnya. Terdapat koordinasi pekerjaan pada semua bawahan, dengan penekanan pada rasa tanggung jawab internal (pada diri sendiri) dan kerja sama yang baik. Kekuatan kepemimpinan demokratis ini bukan terletak pada "person atau individu pemimpin", akan tetapi kekuatan justru terletak pada partisipasi aktif dari setiap warga kelompok.

Menurut Luthans Tiga jenis gaya kepemimpinan dapat dijabarkan sebagai berikut (2012, 577):

1. Gaya Kepemimpinan Autokratis, kepemimpinan autokratis adalah gaya kepemimpinan yang menggunakan metode pendekatan kekuasaan dalam mencapai keputusan dan pengembangan strukturnya, sehingga kekuasaanlah yang paling diuntungkan dalam organisasi. Ciri-ciri gaya kepemimpinan autokratis diantaranya adalah:

a) Human Relationship: Pemimpin kurang memperhatikan kebutuhan bawahan.

b) Communication Skill: Komunikasi hanya satu arah yaitu kebawah saja 
c) Teaching Skill: Pemimpin cenderung menjadi pribadi dalam pujian dan kecamannya terhadap kerja setiap anggota.

d) Social Skill: Pemimpin mengambil jarak dari partisipasi kelompok aktif kecuali bila menunjukan keahliannya.

e) Technical Competent: Membagi tugas kerja bagian dan kerjasama setiap anggota.

2. Gaya Kepemimpinan Demokratis, kepemimpinan demokratis ditandai dengan adanya suatu struktur yang pengembangannya menggunakan pendekatan pengambilan keputusan yang kooperatif. Dibawah kepemimpinan demokratis bawahan cenderung bermoral tinggi, dapat bekerja sama, mengutamakan mutu kerja dan dapat mengarahkan diri sendiri. Ciri-ciri gaya kepemimpinan demokratis diantaranya adalah:

a) Human Relationship: Lebih memperhatikan bawahan untuk mencapai tujuan organisasi.

b) Communication Skill: Selalu mendiskusikan kegiatan.

c) Teaching Skill: Jika dibutuhkan petunjuk teknis pemimpin menyarankan dua atau lebih alternatif prosedur yang dapat dipilih.

d) Social Skill: Pemimpin adalah obyektif dalam pujian dan kecamannya dan mencoba menjadi seorang anggota kelompok biasa dalam jiwa dan semangat tanpa melakukan banyak pekerjaan.

e) Technical Competent: Semua kebijaksanaan terjadi pada kelompok diskusi dan keputusan diambil dengan dorongan dan bantuan dari pemimpin.

3. Gaya Kepemimpinan Laissez-faire (Kendali Bebas), gaya kepemimpinan kendali bebas mendeskripsikan pemimpin yang secara keseluruhan memberikan karyawannya atau kelompok kebebasan dalam pembuatan keputusan dan menyelesaikan pekerjaan menurut cara yang menurut karyawannya paling sesuai. Ciri-ciri gaya kepemimpinan laissez-faire diantaranya adalah:

a) Human Relationship: Pemimpin membiarkan bawahannya untuk mengatur dirinya sendiri.

b) Communication Skill: Pemimpin memberikan komentar spontan terhadap kegiatan anggota atau pertanyaan dan tidak bermaksud menilai atau mengatur suatu kejadian.

c) Teaching Skill: Pemimpin hanya menentukan kebijaksanaan dan tujuan umum.

d) Social Skill: Pemimpin membiarkan bawahannya untuk mengatur dirinya sendiri.

e) Technical Competent: Karyawan dapat mengambil keputusan yang relevan untuk mencapai tujuan dalam segala hal yang mereka anggap cocok.

\section{Kinerja}

Menurut Prawirosenton (1999) adalah merupakan hasil yang dicapai oleh seorang pekerja dalam menjalankan tugas dan fungsinya berdasarkan wewenang dan tanggung jawab masing - masing, dalam rangka mencapai tujuan perusahaan yang tidak melanggar hokum, moral serta etika. Simamora (2006) menyatakan bahwa kinerja (performance) mengacu pada level tercapaianya hasil pekerjaan yang membentuk sebuah pekerjaan karyawan. Mangkunegara (2005) menyebutkan bahwa kinerja adalah prestasi kerja atau hasil kerja (output) baik dalam bentuk kualitas atau kuantitas yang dicapai oleh karyawan pada waktu tertentu pada melaksanakan tugasnya sesuai dengan tanggung jawab yang diberikan kepadanya. Hasil kerja seseorang dalam menyelesaikan tugas bagi keberhasilan organisasi menjadi sebuah penilaian apakah kinerja seorang pekerja itu baik atau buruk hal ini senada dengan pendapat Motowidlo (2003) mendefinisikan bahwa kinerja didasarkan oleh perilaku pegawai dan hasilnya sangat penting bagi keberhasilan organisasi.

Viswesvaran dan Ones (2000) menyatakan bahwa kinerja karyawan merupakan hasil pekerjaan yang mempunyai ukuran yang dilakukan karyawan berhubungan dan berkontribusi pada tujuan organisasi. Simamora (2005: 53) memberikan definisi kinerja karyawan sebagai tingkat hasil kerja karyawan dalam mencapai persyaratan-persyaratan 
pekerja yang diberikan. Dengan kata lain kinerja adalah hasil kerja karyawan dari segi kualitas maupun kuantitas berdasarkan standar kerja yang ditentukan. Kinerja secara umum dipengaruhi tiga faktor, yaitu :

a. Faktor individual yang terdiri dari : kemampuan dan keahlian latar belakang, dimografi.

b. Faktor psikologis yang terdiri dari persepsi, attitude, personality, pembelajaran.

c. Faktor organisasi yang terdiri dari sumber daya, kompensasi, penghargaan, struktur.

Dari uraian di muka maka dapat ditarik kesimpulan bahwa kinerja individu adalah hasil kerja karyawan baik dari segi kualitas maupun kuantitas berdasarkan standar kerja yang telah ditentukan. Hal tersebut akan tercapai apabila didukung oleh atribut individu, upaya kerja (work effort) dan didukung oleh organisasi. Seseorang dapat dikatakan mempunyai kinerja yang baik apabila mereka dapat melaksanakan dan menyelesaikan pekerjaanya berdasarkan tanggung jawab masing - masing.

\section{Indikator Kinerja}

Dari beberapa teori yang dijabarkan diatas mengenai definisi kinerja, penulis mengunakan dimensi sebagai bahan acuan untuk mengisi data operasional variabel dari Sedarmayanti (2009:51) yang meliputi dimensi dan indikator sebagai berikut:

1. Quality of work (kualitas pekerjaan) Kualitas pekerjaan dan kesesuaian hasil dengan standar pekerjaan.

2. Promptness (kecepatan) Penyelesaian tugas tepat waktu dan pekerjaan tercapai sesuai dengan target.

3. Initiative (prakarsa) Memberikan ide-ide untuk menunjang tercapainya tujuan dan mampu memanfaatkan waktu luang.

4. Capability (kemampuan) Mampu menyelesaikan pekerjaan sesuai dengan apa yang diharapkan dan dapat menyelesaikan pekerjaan dengan praktis dan rapi.

5. Communication (komunikasi) Mampu berkomunikasi dengan baik dengan atasan/pimpinan dan sesama rekan kerja.

\section{Sumber Data}

\section{METODOLOGI PENELITIAN}

Populasi dalam penelitian ini adalah semua pegawai pada PT. Persero Bank Tabungan Pensiunan Nasional Purna Bakti Cabang Kutacane sebanyak 13 pegawai. Dengan teknik pengambilan sample yang digunakan maka sebagian yang menjadi sebagian dari populasi yang karakteristiknya hendak diselidiki dan dianggap bisa mewakili keseluruhan populasi atau jumlah lebih sedikit dari populasi. Dalam penelitian ini yang menjadi sampel atau nara sumber penelitian ini ada 4 orang nara sumber.

\section{Analisis Data}

Setelah melakukan pengumpulan data, seluruh data yang terkumpul kemudian diolah oleh peneliti. Data dianalisis menggunakan metode deskriptif kualitatif yaitu dengan mendeskripsikan secara menyeluruh data yang didapat selama proses penelitian. Miles dan Huberman dalam Sugiyono (2012:246) mengungkapkan bahwa dalam mengolah data kualitatif dilakukan melalui tahap reduksi, penyajian data, dan penarikan kesimpulan.

\section{Reduksi}

Mereduksi berarti merangkum, memilih hal-hal pokok dan penting kemudian dicari tema dan polanya (Sugiyono, 2012:247). Pada tahap ini peneliti memilah informasi mana yang relevan dan mana yang tidak relevan dengan penelitian. Setelah direduksi data akan mengerucut, semakin sedikit dan mengarah ke inti permasalahan sehingga mampu memberikan gambaran yang lebih jelas mengenai objek penelitian.

2. Penyajian Data

Setelah dilakukan direduksi data, langkah selanjutnya adalah menyajikan data. Data disajikan dalam bentuk tabel dan uraian penjelasan yang bersifat deskriptif. 


\section{Penarikan Kesimpulan}

Tahap akhir pengolahan data adalah penarikan kesimpulan. Setelah semua data tersaji permasalahan yang menjadi objek penelitian dapat dipahami dan kemudian ditarik kesimpulan yang merupaan hasil dari penelitian ini.

\section{Hasil Penelitian}

\section{HASIL}

\section{Data Deskriptif}

Variabel bebas dalam penelitian ini adalah Motivasi (X1) untuka mengetahui kinerja karyaawan dan Gaya Kepemimpinan (X2) untuk memngetahui kiner karyawan. Adapun struktur organisasi BTPN Purna Bakti Cabang Kutacane dapat dilihat sebagai berikut ;

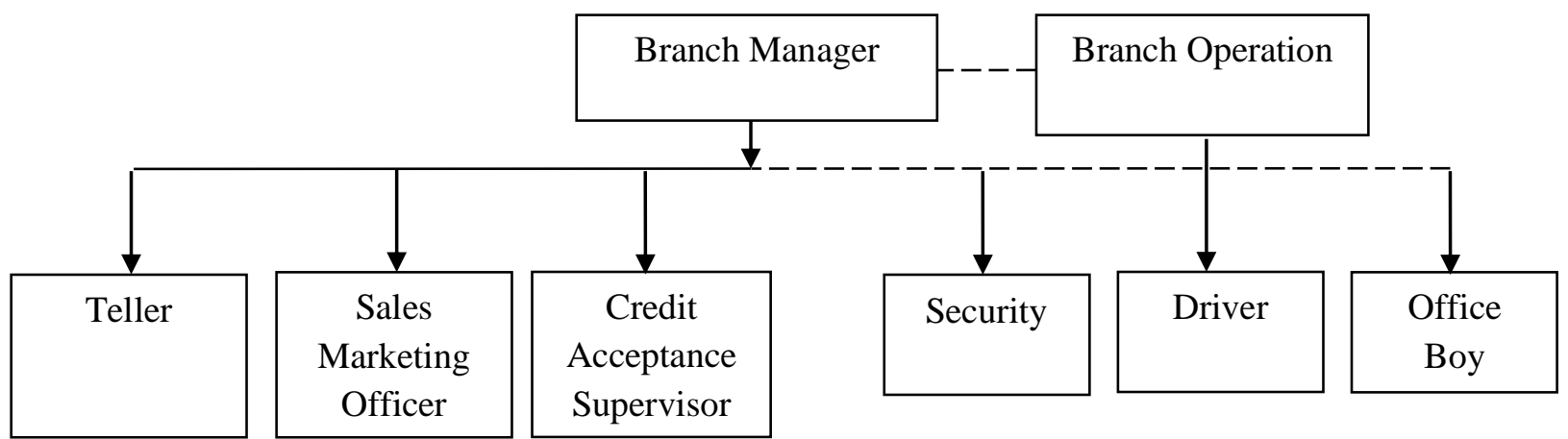

Gambar 1. Struktur Organisasi

\section{Deskripsi Karakteristik Karyawan PT. Persero Bank Tabungan Pensiun Nasional Purna Bakti Cabang Kutacane}

Deskripsi karakteristik karayawan adalah menguraikan atau memberikan gambaran mengenai identitas karyawan PT. Persero Bank Tabungan Pensiun Nasional Purna Bakti Cabang Kutacane dalam penelitian ini, sebab dengan menguraikan karakteristik dalam penelitian ini dapat diketahui sejauh mana identitas karakteristik karyawan yang dikelompokkan menjadi beberapa kelompok yaitu : jenis kelamin, tingkat pendidikan dan usia responden.

1. Jenis Kelamin, Jenis kelamin dalam penelitian ini dapat dikelompokkan dalam 2 kelompok yaitu kelompok laki-laki dan wanita, untuk lebih jelasnya akan disajikan karakteristik pegawai berdasarkan jenis kelamin yang dapat dilihat pada tabel berikut ini :

Tabel 1. Karakteristik Karyawan Berdasarkan Jenis Kelamin

\begin{tabular}{|c|l|r|r|}
\hline NO & \multicolumn{1}{|c|}{ JENIS KELAMIN } & \multicolumn{1}{|c|}{ JUMLAH } & \multicolumn{2}{|c|}{ PERSENTASE } \\
\hline 1 & LAKI-LAKI & 11 & $85 \%$ \\
\hline 2 & PEREMPUAN & 2 & $15 \%$ \\
\hline 3 & TOTAL & 13 & $100 \%$ \\
\hline
\end{tabular}

Sumber : Hasil pengolahan data primer

Dari tabel diatas yakni karakteristik pegawai menurut jenis kelamin dari 13 orang karyawan PT. Persero Bank Tabungan Pensiun Nasional Purna Bakti Cabang Kutacane, maka jenis kelamin yang terbesar adalah laki-laki yakni sebesar 11 orang atau $85 \%$ dan berjenis kelamin perempuan sebesar 2 orang atau $15 \%$.

2. Pendidikan, Pendidikan dalam penelitian ini dapat dikelompokkan dalam 3 kelompok yaitu kelompok Strata 2 (S2), Strata 1 (S1), SMA Sederajat, untuk lebih jelasnya akan 
disajikan karakteristik karyawan berdasarkan pendidikan yang dapat dilihat pada tabel berikut ini

Tabel 2. Karakteristik Karyawan Berdasarkan Pendidikan

\begin{tabular}{|c|l|r|r|}
\hline NO & \multicolumn{1}{|c|}{ PENDIDIKAN } & \multicolumn{1}{|c|}{ JUMLAH } & \multicolumn{1}{|c|}{ PERSENTASE } \\
\hline 1 & S2 & 0 & $0 \%$ \\
\hline 2 & S1 & 11 & $85 \%$ \\
\hline 3 & SMA Sederajat & 2 & $15 \%$ \\
\hline 4 & TOTAL & 13 & $100 \%$ \\
\hline
\end{tabular}

Sumber : Hasil pengolahan data Primer

Dari tabel 2 yakni karakteristik pegawai menurut pendidikan dari 16 orang karyawan PT. Persero Bank Tabungan Pensiun Nasional Purna Bakti Cabang Kutacane, maka pendidikan yang terbesar adalah S1 sederajat yakni sebanyak 11 orang atau $85 \%$, SMA sebanyak 2 orang atau $15 \%$ dan S2 sebanyak 0 orang atau $0 \%$.

3. Usia, Usia dalam penelitian ini dapat dikelompokkan dalam 4 kelompok yaitu kelompok 20-30 tahun, 31-40 tahun, 41-50 tahun dan >50 tahun untuk lebih jelasnya akan disajikan karakteristik pegawai berdasarkan usia dapat dilihat pada tabel berikut ini :

Tabel 3. Karakteristik Karyawan Berdasarkan Usia

\begin{tabular}{|c|l|r|r|}
\hline NO & \multicolumn{1}{|c|}{ LAMA BEKERJA } & \multicolumn{1}{|c|}{ JUMLAH } & \multicolumn{1}{|c|}{ PERSENTASE } \\
\hline 1 & $20-30$ & 10 & $77 \%$ \\
\hline 2 & $31-40$ & 3 & $23 \%$ \\
\hline 3 & $41-50$ & 0 & $0 \%$ \\
\hline 4 & $>51$ & 0 & $0 \%$ \\
\hline 5 & TOTAL & 13 & $100 \%$ \\
\hline
\end{tabular}

Sumber : Hasil pengolahan data Primer

Dari tabel 3 yakni karakteristik pegawai menurut Usia dari 16 orang karyawan PT.

Persero Bank Tabungan Pensiun Nasional Purna Bakti Cabang Kutacane, maka usia yang terbanyak adalah 20-30 tahun yakni sebanyak 10 orang atau $77 \%, 31-40$ tahun sebanyak 3 orang atau 23\%, 41-50 tahun sebanyak 0 orang atau $0 \%$ dan $>51$ tahun sebanyak 0 orang atau $0 \%$.

\section{Pembahasan}

Pemimpin PT. Persero Bank Tabungan Pensiun Nasional Purna Bakti Cabang Kutacane selalu ada upaya untuk memperhatikan kebutuhan karyawan, menurut Bapak Ahmad Yani selaku Baranch Manager PT. Persero Bank Tabungan Pensiun Nasional Purna Bakti Cabang Kutacane, bahwa karyawan merupakan aset bagi perusahaan. Cara perusahaan dalam memenuhi kebutuhan karyawannya adalah dengan meningkatkan kesejahteraan bagi karyawan melalui pemberian fasilitas kesehatan, pendidikan, transportasi yang juga berlaku untuk keluarga karyawan. Pola kepemimpinan yang ada di PT. Persero Bank Tabungan Pensiun Nasional Purna Bakti Cabang Kutacane menurut nara sumber merupakan pola kepemimpinan yang tepat di terapkan di perusahaan, dan hal demikian membuat karyawan memberikan yang terbaik untuk perusahaan. 


\section{A. Human Relationship}

Sejalan dengan Bapak Ahmad Yani, menurut Rio Eldy selaku Credit Acceptance Supervisor PT. Persero Bank Tabungan Pensiunan Nasional Purna Bakti Cabang Kutacane, pemimpin perusahaan memperhatikan kebutuhan karyawan dengan memberikan fasilitas kesehatan, pendidikan, transportasi yang juga berlaku untuk keluarga karyawan karena karyawan merupakan aset yang dimiliki perusahaan, sehingga dengan memberikan perhatian kepada karyawan, diharapkan ada hubungan timbal balik yang diberikan oleh karyawan kepada perusahaan, karena sebuah perusahaan tidak akan bisa berjalan dan beroperasional tanpa adanya keberadaan karyawan. Bahkan tahun 2015 lalu pemimpin PT. Persero Bank Tabungan Pensiunan Nasional Purna Bakti Cabang Kutacane mengadakan family gathering ke Pante Goyang dengan para karyawan dan keluarga karyawan, pemimpin perusahaan juga ikut mengajak anak dan istrinya.

Hal ini dapat meningkatkan keakraban sesama karyawan serta keluarga besar karyawan PT. Persero Bank Tabungan Pensiunan Nasional Purna Bakti Cabang Kutacane. Menurut Bapak M. Harun Arrasyid selaku Sales Marketing Officer PT. Persero Bank Tabungan Pensiunan Nasional Purna Bakti Cabang Kutacane, keakraban juga dibutuhkan oleh kelaurga besar karyawan PT. Persero Bank Tabungan Pensiunan Nasional Purna Bakti Cabang Kutacane, dengan semakin akrabnya dan membaiknya jalinan sosial semakin kuatnya perusahaan.

\section{B. Communication Skill}

Menurut Wahyu Saputra selaku karyawan Sales Marketing Officer PT. Persero Bank Tabungan Pensiunan Nasional Purna Bakti Cabang Kutacane. dalam menjalin komunikasi dengan karyawan, perusahaan memberlakukan adanya meeting di tiap bulannya yang ditujukan untuk membahas ide-ide atau gagasan dari karyawan serta target karyawan, dan membahas keluhan yang disampaikan karyawan, sehingga ada sarana diskusi antara pemimpin dan karyawan perihal target kinerja yang terdapat di perusahaan. Dalam meningkatkan kinerja karyawannya untuk menjadi lebih baik, pemimpin perusahaan memberikan pengertian bahwa kegiatan kerja yang dilakukan oleh karyawan, keuntungannya bukan hanya untuk perusahaan, tetapi juga untuk keluarga karyawan dan karyawan sendiri. Sejalan dengan ini, menurut M. Harun Arrasyid selaku Sales Marketing Officer PT. Persero Bank Tabungan Pensiunan Nasional Purna Bakti

Cabang Kutacane dalam melakukan komunikasi, perusahaan juga memberlakukan intruksi atau pemberitahuan berupa pengumuman yang ditempelkan di papan kerja di perusahaan dengan tujuan untuk mempermudah karyawan dalam memperoleh informasi dalam kaitannya terhadap kelangsungan kegiatan pekerjaan.

\section{Teaching Skill}

Dalam menjalankan produk baru, maupun keputusan serta target dari Pimpinan Pusat PT. Persero Bank Tabungan Pensiunan Nasional Purna Bakti langsung diadakan meeting yang dibawakan oleh Branch Manager PT. Persero Bank Tabungan Pensiunan Nasional Purna Bakti Cabang Kutacane. Menurut Ahmad Yani, selaku Branch Manager PT. Persero Bank Tabungan Pensiunan Nasional Purna Bakti Cabang Kutacane Contoh, jika ada produk yang baru, perusahaan langsung mengadakan meeting untuk presentasi tentang produk tersebut. Lalu langsung dicoba untuk instalasinya, dari sana akan terlihat kendala dari penggunaan produk yang baru ini seperti apa dan bagaimana prosesnya.

D. Social Skill

Menurut Bapak M. Harun Arrasyid, selaku Sales Marketing Officer PT. Persero Bank Tabungan Pensiunan Nasional Purna Bakti Cabang Kutacane hubungan antara pemimpin dan karyawan di PT. Persero Bank Tabungan Pensiunan Nasional

Purna Bakti Cabang Kutacane merupakan hubungan yang baik, karena bagi pemimpin perusahaan, karyawan di anggap sebagai partner kerja, bukan sebagai atasan dan bawahan. Pemimpin perusahaan juga sering makan malam dengan karyawan ramai-ramai saat setelah selesai kerja dan mentraktir karyawannya. 
Perihal untuk kepentingan menjaga kewibawaan di hadapan karyawan, pemimpin juga tidak pernah menjaga jarak, karena baik pemimpin maupun karyawan perusahaan sudah mengetahui status dan porsi masing-masing di perusahaan disaat jam kerja dan disaat selesai jam kerja, seperti pemimpin perusahaan sering ngobrol dengan karyawan disaat setelah selesai kerja. Pemimpin sudah memberikan garis besar di perusahaan perihal visi, misi dan goal perusahaan, baik bagi karyawan baru maupun bagi karyawan yang lama.

\section{E. Technical Competence}

Menurut Rio Eldy selaku Credit Acceptance Supervisor PT. Persero Bank Tabungan Pensiunan Nasional Purna Bakti Cabang Kutacane Pemimpin PT. Persero Bank Tabungan Pensiunan Nasional Purna Bakti Cabang Kutacane membuat dan menetapkan kebijaksanaan di perusahaan seperti peraturan tata tertib perusahaan, sistem perusahaan dan sistem kerja. Peraturan seperti absen kehadiran kerja paling lambat jam 8 pagi, untuk staf yang bekerja di kantor harus memakai seragam perusahaan, jam 12 istirahat untuk makan siang dan jam 1 siang harus sudah bekerja lagi. Kalau untuk sistem perusahaan, perusahaan ini semua sudah menggunakan komputer untuk operasionalnya, semua tempat terdapat instalasi camera cctv wireless agar pemimpin tetap bisa mengontrol aktivitas di perusahaan dari jarak jauh kalau pemimpin sedang ada janji ketemu client disaat pagi atau siang hari. M. Harun Arrasyid, selaku Sales Marketing Officer PT. Persero Bank Tabungan Pensiunan Nasional Purna Bakti Cabang Kutacane sebuah keputusan yang berkaitan dengan pekerjaan tidak selalu dikeluarkan oleh pemimpin saja, tergantung kasusnya, kalau karyawan tidak bisa menyelesaikan, pemimpin akan turun tangan.

\section{F. Kinerja}

PT. Persero Bank Tabungan Pensiunan Nasional Purna Bakti Cabang Kutacane dalam menilai kinerja karyawan adalah dengan berdasarkan pada point-point yang digunakan oleh perusahaan sebagai parameter untuk mencapai target perusahaan yaitu kualitas, kuantitas, penghematan waktu dan efisiensi biaya. Pengawasan terhadap pelaksanaan pekerjaan yang terdapat di perusahaan, pemimpin tidak selalu melakukannya, karena dalam perusahaan sendiri sudah memiliki divisi quality control. Pemimpin perusahaan juga tidak pernah membedakan status karyawan yang sudah menikah dan belum menikah, baik pada saat perekrutan maupun pada saat bekerja, hal demikian dilakukan oleh perusahaan untuk hasil kinerja karyawan yang maksimal. Oleh karena itu, dari keseluruhan hasil kinerja karyawan, dampak yang diterima oleh perusahaan adalah hasil dari kinerja karyawan yang sesuai dengan keinginan dan ketentuan perusahaan. Menurut penuturan Bapak Ahmad Yani, selaku Branch Manager PT. Persero Bank Tabungan Pensiunan Nasional Purna Bakti Cabang Kutacane, bahwa kinerja karyawan PT. Persero Bank Tabungan Pensiunan Nasional Purna Bakti Cabang Kutacane dipresentasekan sekitar 90\% atas kinerja perusahaan.

G. Pengaruh motivasi,

motivasi merupakan aspek utama dalam seorang pekerja memilih untuk bekerja dan bertahan pada sebuah perusahaan.Aspek ini memberi dorongan dalam melaksanakan dan menyelesaikan tugas serta kewajiban seorang pegawai.Terdapat banyak aspek yang menjadi indicator pada penilaian motivasi seseorang untuk bekerja. Dalam hal beberapa aspek yang menjadi pilihan responden, factor penghargaan pada motivasi merupakan alasan yang umum terjadi pada pegawai Bank, dimana pencapaian perhatian dan pengakuan tempat bekerja menjadi alasan motivasi terjadi. Hal ini diperjelas oleh pegawai yang menjadi informan peneliti: dengan cara memberikan petunjuk - petunjuk yang sesuai dengan SOP dan semangat akan pekerjaan yang akan dilakukan dan dampak positif bagi nasabah. Atasan selalu menekankan untuk bekerja ikhlas dan penuh tanggung jawab Informaan TJ "Memberi nasehatnasehat, memberikan masukan bagaimana bekerja dengan baik sesuai SOP, dan rutin mengadakan rapat/breafing" (Informan RI) Atasan kerap kali memotivasi 
saya dengan mengajak untuk bekerja ikhlas dan cerdas, karena setiap hasil dari jerih payah tidak pernah mendustai proses (Informan IF) Atasan memotivasi dengan cara memberikan nasihat yang baik dan memberikan contoh yang baik pada karyawan yang dijalankan sesuai dengan SOP jawaban dari informan secara tidak langsung menyatakan bahwa penghargaan merupakan aspek yang membuat motivasi kerja muncul.informan TJ menyatakan atasan memberikan petunjuk sesuai SOP dan pekerjaan akan memberikan dampak positif bagi nasabah serta bekerja dengan ikhlas dan bertanggung jawab. Informan RI menyatakan atasan memberikan nasehat, memberikan masukan bagaimana cara bekerja yang baik sesuai SOP dan rutin mengadakan rapat. Informan IF menyatakan atasan kerap mengajak untuk bekerja ikhlas dan cerdas.Kemudian informan BK menyatakan atasan sering memberikan contoh yang baik pada karyawan dalam bekerja.

Selain penghargaan dalam motivasi kerja ada pula poin fisiologi yang menjadi factor pekerja motivasi terhadap tugas dan tanggung jawabnya. Hal ini diperjelas dengan jawaban dari dua informan: Hal yang memotivasi saya untuk bekerja pada perusahaan ini adalah karena perusahaan ini memberikan jaminan yang jelas dari sisi financial Informan TJ: hal yang memotivasi saya untuk bekerja pada perusahaan ini karena tawaran gaji yang banyak.

Informan NS, Kedua informan sepakat gaji merupakan factor dalam motivasi kerja. Informan TJ menyatakan perusahaan memberikan jaminan yang jelas dari sisi financial. Informan NS menyatakan perusahaan memberikan tawaran gaji yang banyak. Selain factor penghargaan dan financial factor aktualisasi diri merupakan factor yang juga menjadi jawaban yang kerap muncul dalam penelitian ini yang diperjelas oleh dua informan yaitu: peluang yang diberikan sama dengan latar belakang pendidikan saya yaitu pada bidang IT.

Informan TJ : karena saya yakin apabila saya bekerja di perusahaan ini saya memiliki jenjang karir yang cemerlang dan lebih baik.

Informan BK, Kedua informan menilai aktualisasi diri juga merupakan hal yang penting dalam motivasi kerja.Informan TJ menitik beratkan penilaian pendidikan yang selaras dengan tawaran kerja yaitu pada bidang IT.Informan BK menilai jenjang karir yang cemerlang dan lebih baik menjadi motivasi bekerja.

Berdasarkan penjelasan diatas dapat dinyatakan tiga faktor yang menjadi hal utama yang menjelaskan motivasi kerja pegawai Bank yaitu penghargaan, fisiologi dan aktualisasi diri.Cara Bank membuat dan menciptakan lingkungan kerja yang kondusif serta baik dan cara memotivasi pekerja oleh atasan akan menjadikan dampak yang baik pula pada perusahaan. Kemudian dapat dilihat pada aspek penghargaan disamping pada nasehat dan rapat, SOP merupakan standar kerja yang menjadi dasar atasan mengawasi, menilai dan menasehati agar prestasi kerja dapat muncul serta pelayanan terhadap nasabah akan terus meningkat.

\section{KESIMPULAN}

Dari hasil penelitian, dapat disimpulkan bahwa:

1. motivasi yang dominan pada penelitian ini adalah penghargaan walaupun tidak menepikan faktor yang lainnya, penghargaan yang diberikan perusahaan atau atasan menurut responden adalah lebih dominan dibandingkan factor fisiologi, rasa aman, social danaktualisasi. Hal ini menunjukkan bahwa perhatian yang diberikan oleh atasan baik itu berupa saran atau nasehat serta bantuan teknis merupakan factor yang membuat seorang karyawan lebih termotivasi terhadap tanggung jawab mereka. Karyawan merasa lebih dibutuhkan serta bagian penting dari perusahaan karena pengawasan yang kerap diberikan oleh atasan mereka.

2. Gaya kepemimpinan Demokratis yang terdapat di PT. Persero Bank Tabungan Pensiunan Nasional Purna Bakti Cabang Kutacane dapat di nilai dari: Memperhatikan kebutuhan karyawan 
3. Selalu melakukan musyawarah untuk hasil yang terbaik bagi perusahaan dan karyawan.

4. Kondisi tertentu, baik antara karyawan maupun pemimpin saling memberikan informasi perihal keputusan yang diambil oleh karyawan dan pemimpin memberikan persetujuannya.

5. Pemimpin selalu memberikan motivasi kepada karyawan untuk bisa bekerja dengan baik, dan memberikan reward dalam bentuk bonus kepada karyawan yang menunjukkan kinerjanya.

6. Tingkat sosial pemimpin sangat tinggi kepada karyawan

7. Pemimpin memberikan hak kepada karyawan dalam hal pengambilan

8. Kinerja karyawan PT. Persero Bank Tabungan Pensiunan Nasional Purna Bakti Cabang Kutacane di dasarkan pada point-point penilaian kinerja karyawan yang digunakan sebagai parameter dalam mencapai target perusahaan. Parameter yang digunakan adalah kualitas kinerja, kuantitas, penghematan waktu dan efisiensi biaya.

Buku:

\section{DAFTAR PUSTAKA}

[1] Arikunto, Suharimi. 2002. Prosedur Penelitian: Suatu Pendekatan Praktek. Rineka Cipta. Jakarta.

[2] Djarwanto PS dan Pangestu Subagyo ,2006, Statistik induktif, Edisi keempat, BPFE UGM, Yogyakarta.

[3] Flippo, Edwin B, Manajemen Personalia, Jilid I, Edisi ke tujuh, Alih Bahasa Moh. Masud, Penerbit Airlangga, Jakarta, 2004.

[4] Ghozali,Imam.2005, Analisis Multivariate Dengan Program SPSS, Edisi Ketiga, Badan Penerbit Universitas Diponegoro, Semarang.

[5] Hasibuan, M. H., 2002. Manajemen Sumber Daya Manusia. Jakarta: PT Bumi Aksara.

[6] Hamalik, Oemar, Pendidikan Pegawai : Konsep Kurikulum, Strategi, Pustaka Martianana, Bandung, 2005.

[7] Handoko, H., 2001, Manajemen Personalia dan Sumher Daya Manusia. Yogyakarta: BPFE-Yogyakarta

[8] Ibrahim, Rusli, Pengembangan Inovasi Kerikulum, Depdikbud, Jakarta, 2000.

[9] Kumorotomo Wahyudi, Etika Administrasi Negara, PT. Raja Grafindo Persada, Jakarta, 2002

[10] Manullang, M., Manajemen Personalia, Cetakan kesebelas, Penerbit Ghalia Indonesia, Jakarta, 2005.

[11] Martoyo, Susilo, Manajemen Sumber Daya Manusia, Penerbit BPFE, Yogjakarta, 2007.

[12] Moekijat, Manajemen Kepegawaian, Penerbit Alumni, Bandung, 2009.

[13] Prawirosentono, Suyadi. 2009. Manajemen Sumber Daya Manusia: Kebijakan Kinerja Karyawan. BPFE. Yogyakarta.

[14] Proctor, John H. dan William Thorton, Manajemen Kepegawaian, terjemahan Moekijat Penerbit Alumni, Bandung. 2009. 
[15] Ranupandojo, Heidjrachman dan Suad Husnan, 2002. Manajemen Personalia, Edisi Keempat, Penerbit BPFE, Yogyakarta

[16] Veithza Rivai. 2011. Manajmen dan Evaluasi Kinerja. Obor. Jakarta

[17] Robbins, Stephens P, 2001. Perilaku Organisasi, Edisi Indonesia. Indeks. Jakarta

[18] Sedarmayanti. 2001. Sumber Daya Manusia dan Produktivitas Kerja. Mandar Maju. Bandung.

[19] Sugiyono, 2007, Metode Penelitian Kuantitatif, Kualitatif R\&D, Cetakan ke-tiga, Penerbit Alfabeta, Bandung

[20] Simamora. Henry. 2002. Akuntansi Manajemen. Edisi ke-11. UPP AMP YKPN. Yogyakarta

[21] Singarimbun, Masri dan Effendi, Sofian. 1989. Metode Penelitian Survai. -Rev. Ed-. LP3S. Jakarta.

[22] Siswanto, Bedjo, Manajemen Tenaga Kerja Ancaman dalam Pendayagunaan dan Pengembangan Unsur Tenaga Kerja, Penerbit Airlangga, Jakarta, 2007.

[23] Tim penyusun, Profesionalisasi Jabatan Pegawai, Direktorat Jenderal Pendidikan Tinggi Jakarta, 2003.

[24] Husein Umar, (2004), Metode Penelitian Untuk Skripsi Dan Teori Bisnis, Edisi baru8, Penerbit PT RajaGrafindo Persada, Jakarta 